\title{
Marine and brackish-water molluscan biodiversity in the Gulf of California, Mexico
}

\author{
MICHEL E. HENDRICKX ${ }^{1}$, RICHARD C. BRUSCA ${ }^{2}$, MERCEDES CORDERO ${ }^{3}$ and \\ GERMÁN RAMÍREZ R. ${ }^{1}$ \\ ${ }^{1}$ Universidad Nacional Autónoma de México, Instituto de Ciencias del Mar y Limnología, Unidad Académica Mazatlán, \\ Laboratorio de Invertebrados Bentónicos E-mail: michel@ola.icmyl.unam.mx \\ 2 Arizona-Sonora Desert Museum, Tucson, Arizona, USA. \\ ${ }^{3}$ B.I.A., Universidad Nacional Autónoma de México, Instituto de Ciencias del Mar y Limnología, Unidad Académica \\ Mazatlán, Laboratorio de Invertebrados Bentónicos México.
}

\begin{abstract}
SUMMARY: A database containing taxonomic, distributional and ecological data of 2194 species of marine molluscs (1528 Gastropoda, 565 Bivalvia, 59 Polyplacophora, 21 Scaphopoda, 20 Cephalopoda, and one Monoplacophora) known to the Gulf of California, Mexico, was used to analyse their latitudinal and bathymetric distribution, to define their substrate preferences, and to elaborate a biodiversity model for the study area. The model was based on a comparison between the set of data associated with each species (i.e., depth range, associated substrates and geographic distribution within the Gulf) and the environmental conditions prevailing in the Gulf (i.e., depth and substrate), using a georeferenced grid of $2 \times 2$ nautical miles. Results are presented as predictive biodiversity distribution maps for the major molluscan groups. Putative biodiversity ranges were defined using a percentage accumulative system with $20 \%$ classes. As expected, the highest biodiversity occurs along the coastline and around the islands. A south-north biodiversity gradient is observed, although it is less evident between the southern and central Gulf.
\end{abstract}

Keywords: Mollusca, biodiversity, Gulf of California, Mexico.

RESUMEN: BIODIVERSIDAD DE LOS MOLUSCOS MARINOS Y DE AGUAS SALOBRES EN EL GOLFO DE CALIFORNIA, MÉXICO. - Una base de datos conteniendo información taxonómica, de distribución y datos ecológicos de 2194 especies de moluscos marinos (1528 Gastropoda, 565 Bivalvia, 59 Polyplacophora, 21 Scaphopoda, 20 Cephalopoda y un Monoplacophora) conocidos para el golfo de California, México, fue utilizada para analizar su distribución latitudinal y batimétrica, para definir su afinidad por los distintos substratos, y para elaborar un modelo de la biodiversidad para el área del estudio. El modelo fue basado en una comparación entre el sistema de los datos asociados con cada especie (i.e., intervalo de profundidad, substratos asociados, distribución dentro del golfo) y las condiciones ambientales (i.e., profundidad y substrato) prevalecientes en el golfo, usando una retícula georeferenciada de $2 \times 2$ millas náuticas. Los resultados se presentan como mapas de distribución de la biodiversidad para Bivalvia, Gastropoda, y para el resto de los grupos. Las gamas supuestas de la biodiversidad fueron definidas usando un sistema acumulativo del porcentaje con las clases del $20 \%$. Según lo esperado, la biodiversidad más alta se encuentra a lo largo de la línea de la costa y alrededor de las islas. Se observa un gradiente de la biodiversidad del sur-norte, aunque es menos evidente entre la parte sur y central del golfo.

Palabras clave: Mollusca, biodiversidad, golfo de California, México.

\section{INTRODUCTION}

Large-scale biodiversity studies are rarely accomplished in marine tropical areas. This is primarily due to a basic lack of infrastructure and expertise in these regions (Hatcher et al., 1989; McNeely et al., 1990). However, the study of healthy tropical ecosystems requires priority attention before irreversible damage occurs. Indeed, rapid human population increases and the large 
impact of tourist developments along subtropical and tropical coasts of the world are already having disastrous effects on native flora and fauna (Thorpe et al., 1995; May, 1992; Ibarra Obando, 1998).

The need to assess the status of natural marine communities has long been noted. In the tropics, natural communities comprise thousands of species which all play strategic roles in the multiple ecological and biological processes (Solow, 1995; Poore and Wilson, 1993). Furthermore, sustainable use of marine and coastal living resources cannot be properly established without an adequate knowledge of biodiversity. In the broad sense, biodiversity not only addresses the variety (or number) of species; it also concerns the variety of organism sizes and shapes, the diversity of micro-habitats available to the flora and fauna, the structure of food webs and trophic levels, and the number of relationships that can be observed within a natural community. Ultimately, monitoring the biodiversity of a large ecosystem will allow a proper evaluation of the effects of natural (e.g., hurricanes and currents) and anthropogenic (e.g., pollution, introduction of alien species, destruction of microhabitats and fishing practices) factors on species numbers, kinds and distribution.

Documenting biodiversity ultimately depends upon the sampling effort and systematic knowledge of local fauna and flora. A short, extensive sampling effort can lead to a high biodiversity if analysis of the collected fauna is performed by qualified experts. On the contrary, a long-term sampling programme might prove to be inadequate if appropriate expertise is lacking. The Gulf of California is the region of the tropical eastern Pacific where the greatest sampling effort has been performed. Scientific contributions first originated from a series of expeditions and specific sampling efforts by U.S. institutions. More recently, local Mexican institutions have greatly contributed to our knowledge of this semi-enclosed marine region, and there are now hundreds of available papers dealing with the area (see Brusca et al. 2005, Hendrickx et al. 2005).

Compilation and synthesis of primary information that is now readily available in published works is a time-consuming endeavour that few institutions can afford to do. Since 1993, however, a significant effort has been made by a group of scientists in order to establish a taxonomic, ecological and distributional database of Gulf of California marine and brackish water fauna. The results presented herein are part of this effort (see Hendrickx et al., 2005).

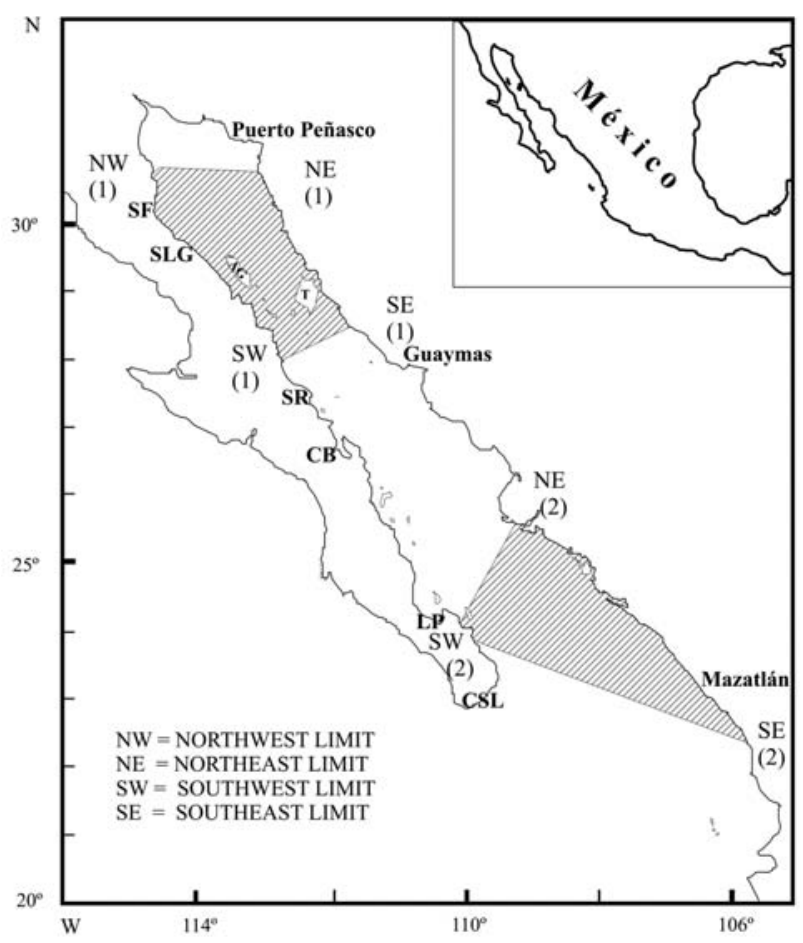

FIG. 1. - Distribution polygons using four extreme localities (species 1) and three extreme localities (species 2) within the Gulf of California.

\section{STUDY AREA}

The study area considered herein corresponds to the Gulf of California as defined by Hendrickx (1992), Hendrickx et al. (2005), and Brusca et al. (2005). The northern boundary is at the mouth of the Colorado River and the southern limits are Cabo San Lucas (Baja California Sur) and Cabo Corrientes (Jalisco) - the southern extremity of Banderas Bay, on the mainland coast (Fig. 1). Thus, this definition of the "Gulf of California" includes the entire mouth area of this otherwise enclosed sea. This southern limit differs somewhat from several previous definitions of the Gulf's southern boundary. It finds justification in several factors, and follows the definition and protocols of the "Macrofauna Golfo" Project (Brusca et al., 2005). First, the area extending south of Topolobampo-Mazatlan, two localities often considered as the southernmost limit of the Gulf of California, has a geomorphology similar to the coastal stretch extending north to Guaymas (i.e., long stretches of sandy beaches, few rocky points, ample areas of coastal lagoons, estuaries and esteros, and a regularly sloping shelf). Second, recent studies on stomatopod and decapod crustacean distribution (Hendrickx and Salgado- 
Barragán, 1991; Hendrickx, 1992) have demonstrated that most species found in the southern half of the Gulf of California are tropical species that range all the way to Central America, Colombia or even further south to northern Peru. Furthermore, water temperatures in this part of the Gulf follow a similar seasonal pattern, with shallow-water maximum temperature differences of less than 5 degrees Celsius for any given season of the year and subtidal epibenthic temperature essentially consistent below $90 \mathrm{~m}$ depth (Hendrickx, 1992). The Gulf of California area, as defined herein, does not necessarily match the Cortés ("Cortez") zoogeographical Province of some authors. Indeed, the exact position of the southern boundary of this subtropical province has been "debated" in many previously published papers (e.g., Brusca and Wallerstein, 1979).

As such, the Gulf of California is a large body of water, extending roughly over $283,000 \mathrm{~km}^{2}, 400 \mathrm{~km}$ across in its widest part (measured along parallels), and reaching abyssal depths in its southern region $(>2000 \mathrm{~m})$ and in basins $(>3500 \mathrm{~m})$. The coastal length is estimated at $4512 \mathrm{~km}$. Coastal measurements were made using a digital map which provided a $235 \mathrm{~m}$ definition, i.e., one pixel represented 235 $\mathrm{m}$. Of these $4512 \mathrm{~km}$, about half is occupied by sandy shores, a dominating feature on the east and northern coasts; rocky shores and cliffs are characteristic of the Baja California peninsular coast, while a regular fresh water supply is almost exclusively restricted to the SE extremity of the Gulf where coastal lagoons and estuaries dissect the coastal plain (Parker, 1964; Brusca, 1980; Hendrickx, 1992; Brusca et al., 2004).

\section{METHODS}

The main purpose of this study is to propose a georeferenced model of molluscan biodiversity in the Gulf of California. To attain this objective, two major databases were used: a taxonomic database including species distributions, and a georeferenced environmental database. The taxonomic database was built with scientific names of all species known to occur in the Gulf, each species entry being associated with a series of ecological data fields (e.g., habitat and bathymetric distribution) and geographic distribution data (i.e., the area of the gulf in which the species occurs). Major habitats (e.g., rocky intertidal, sandy beaches and corals) and bathymetric distribution (e.g., 25-120 $\mathrm{m})$ for each species, and its geographic distribution, were based on both published and unpublished data (see Findley and Brusca, 2005, for a description of the "Macrofauna Golfo Database"). Specific ecological data associated with species or collection records are often scarce; however, it is generally feasible to associate a species with a general habitat. Species included in the Macrofauna Golfo Database were assigned to eight major habitats: sandy shore, rocky shore, pebble beach, mangrove forest, coral reef, muddy bottom, marine vegetation (epiphytic species) and "water column" (pelagic species). Intertidal species are those known to occur from supralittoral to infralittoral horizons. Geographic distribution for each species was transformed into a distribution polygon defined by a maximum of four locality limits within the Gulf of California; these four localities (NW distributional limit, SW distributional limit, NE distributional limit and SE distributional limit) were identified in the taxonomic database by their respective latitude and longitude. For obvious reason, species with only three, two or one known localities within the Gulf feature a distinctly shaped distribution pattern (see Fig. 1) and these were represented by only three, two or one latitude-longitude combination in the database. For species occurring along the mainland coast (e.g., at Guaymas) and at any given point south of Cape Corriente (e.g., Golfo Dulce, Costa Rica), the SE distribution limit was automatically set at Cape Corrientes, the southernmost locality considered as part of the study area.

The environmental database was constructed using both published and unpublished data on depth and substrate using regional maps. Most significant published data and references were obtained from Parker (1964), Keen (1971), Brusca (1980), van der Heiden and Hendrickx (1982), and Skoglund (1991, 1992) (see Hendrickx et al., 2005, for a complete list of references).

A grid of squares, each two nautical miles across (equivalent to a square of $2 \times 2$ minutes) was established for the entire Gulf area (Fig. 2). Each square was identified by its latitude and longitude using the central point of each square, a depth range, and a type of substrate. In the coastal area, it was often necessary to assign more than one substrate to some squares due to habitat changes over distances smaller than two nautical 


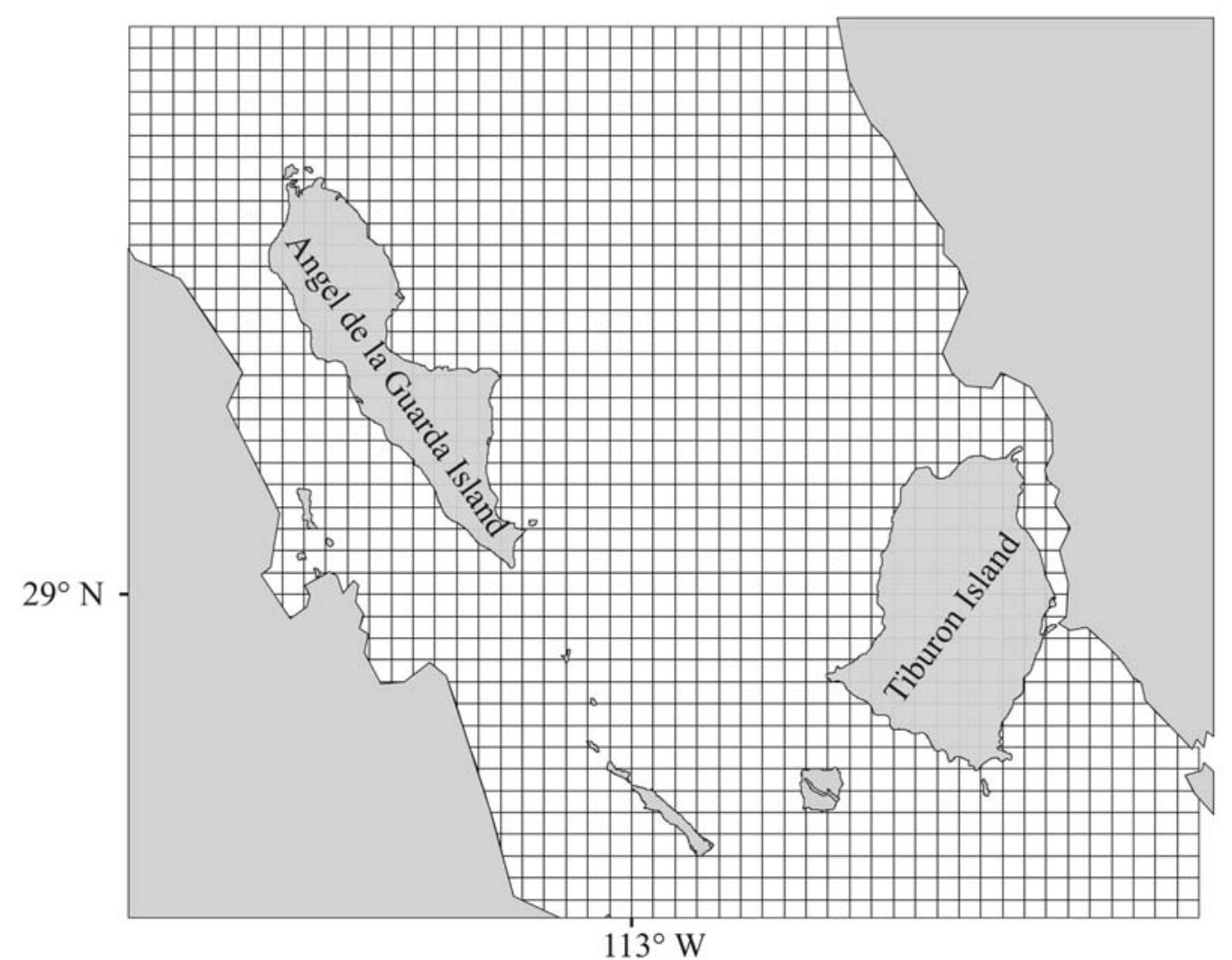

FIG. 2. - Definition of $2 \mathrm{~nm} \times 2 \mathrm{~nm}$ grid. Area represented corresponds to the Central Gulf of California between Angel de la Guarda and Tiburon islands.

miles. In all cases the data associated with each square had to be adjusted according to available data; for instance, bathymetric maps available for the Gulf feature successive isobaths for 100, 200, $500,1000,1500,1800,2000,2500 \mathrm{~m}$ etc., thus providing ample depth range for any given square of the grid. Because intertidal habitat is often very narrow and could not be defined accurately using a 2 by $2 \mathrm{~m}$ grid, all squares or fractions of squares adjacent to the coast (either peninsular, insular, or continental) were arbitrarily given a depth range of $0-20 \mathrm{~m}$, thus including all strictly intertidal species, intertidal species extending to deeper water, or species featuring a minimum depth distribution range $<21 \mathrm{~m}$. To complete the analysis, numbers of mollusc species considered "strictly intertidal" according to published or available unpublished records were sorted and results are presented in a table. Our knowledge of sediment distribution within the Gulf is rather sketchy, and for many coastal areas specific data are lacking. Still, the resulting environmental database is consistent with our present knowledge of existing major habitats and allows a preliminary model of the biodiversity distribution to be established for the region.
A comparative computer program (BIODIX-1) was designed in order to compare the two databases. Whenever the data (i.e., depth, substrate and species range) associated with a given species matched the data for the same parameters associated with a square, this square was assigned a count of one "biodiversity unit" (i.e., one species present in this square). The final number of species that match any given square was considered the "biodiversity potential" for that square. In other words, a secondary matrix providing the number of potential species for each square was obtained. This data comparison was done for all species of molluscs known to occur in the Gulf of California. Putative biodiversity ranges were defined using a percentage accumulative system with $20 \%$ classes. In this system, biodiversity values of $0,1,2$ etc. are selected until the accumulated number of squares with these values represents at least $20 \%$ of the total number of squares in the grid. The procedure is then repeated for the second interval (up to or slightly $>40 \%$ ) until $100 \%$ of the squares have been selected. The resulting biodiversity ranges (e.g., 0-2, 3-5, 6-20, 21-100 and 101-350) are then colour-coded on maps. 


\section{RESULTS}

\section{Biodiversity and species affinity within major habitats}

The molluscan fauna of the Gulf of California comprises 2194 recorded, named species. A complete list of these species is presented by Hendrickx et al. (2005). With a total of 1528 species, Gastropoda is by far the most species-rich group, followed by Bivalvia, 565 species. Together, these two groups far outnumber the rest and represent 95.3\% of the total mollusc species known from the gulf. Polyplacophora include 59 species, Scaphopoda 21 species, Cephalopoda 20 species, and there is one species of Monoplacophora known from the area (Tables 1-3).

The 565 species of bivalves known from the Gulf of California belong to 67 families. The number of species per family varies considerably (from 1 to 72 species). Ten families (15\%) contain a single species, a much lower figure than in Gastropoda, while 7 families contain 20 or more species. The most diverse families are Veneridae (72 species) and Tellinidae (54 species) (Table 1). Data related to substrate are available for 458 species (Table 4). A large majority of species is associated with sandy (329 species) and muddy (243 species) substrates. A lower proportion of bivalves is found on rocky substrates (141) and on pebbly substrates (44), while a significant number of species are found associated with marine vegetation (137 species). Mangrove habitats host 73 bivalve species, although in this case most species described from mangrove habitats are probably burrowing species associated with muddy or sandy benthic substrates in mangrove lagoons.

Gastropods of the Gulf belong to as many as 135 families, with 1 to 184 species per family (Table 2). Thirty-nine families $(29 \%)$ contain a single species, whereas 21 families contain 20 or more species. The most diverse families are Turridae (184 species) and Pyramidellidae (152 species). Affinity for substrates is available for 953 species (Table 4). A large majority of species are associated with rocky substrates and pebbles (757 species). Surprisingly, only 22 species have a positive, published record of association with corals, whereas at least 35 species are known to be associated with mangrove forests. Sandy substrates at shallow and intermediate depths are the favourite habitats for 300 species, while muddy substrate is preferred by 224 species. Thirty-
TABle 1. - Number of species of Pelecypoda known from the Gulf of California. Data presented by family.

\begin{tabular}{|c|c|c|c|}
\hline Family & No. species & Family & No. species \\
\hline Acharacidae & 1 & Nucinellidae & 1 \\
\hline Anomiidae & 4 & Nuculanidae & 16 \\
\hline Arcidae & 31 & Nuculidae & 6 \\
\hline Bernardinidae & 2 & Ostreidae & 7 \\
\hline Cardiidae & 17 & Pandoridae & 6 \\
\hline Cardiniidae & 1 & Pectinidae & 20 \\
\hline Carditidae & 6 & Periplomatidae & 7 \\
\hline Condylocardiidae & 1 & Petricolidae & 6 \\
\hline Cooperellidae & 2 & Philobryidae & 1 \\
\hline Corbiculidae & 3 & Pholadidae & 10 \\
\hline Corbulidae & 12 & Pinnidae & 4 \\
\hline Crassatellidae & 9 & Placunidae & 1 \\
\hline Cultellidae & 2 & Plicatulidae & 4 \\
\hline Cuspidariidae & 7 & Poromyidae & 2 \\
\hline Chamidae & 14 & Psammobiidae & 16 \\
\hline Dimyidae & 1 & Pteriidae & 2 \\
\hline Donacidae & 11 & Sareptidae & 1 \\
\hline Erycinidae & 3 & Semelidae & 27 \\
\hline Galeommatidae & 4 & Solemyidae & 2 \\
\hline Gastrochaenidae & 3 & Solenidae & 4 \\
\hline Glycymerididae & 8 & Spheniopsidae & 2 \\
\hline Gryphaeidae & 2 & Spondylidae & 3 \\
\hline Hiatellidae & 2 & Sportellidae & 8 \\
\hline Isognomonidae & 2 & Tellinidae & 54 \\
\hline Kelliidae & 7 & Teredinidae & 7 \\
\hline Leptonidae & 2 & Thraciidae & 10 \\
\hline Limidae & 5 & Thyasiridae & 2 \\
\hline Lucinidae & 23 & Ungulinidae & 8 \\
\hline Lyonsiidae & 4 & Veneridae & 72 \\
\hline Mactridae & 14 & Verticordiidae & 4 \\
\hline Malleidae & 1 & Vesicomyidae & 3 \\
\hline Montacutidae & 11 & & \\
\hline Myidae & 2 & & \\
\hline Mytilidae & 28 & Total species & 565 \\
\hline Neilonellidae & 1 & Total families & 67 \\
\hline Noetiidae & 3 & & \\
\hline
\end{tabular}

one species have been found associated with marine flora (other than mangrove) and six species are pelagic. Substrate association is not clearly stated in the published literature for as many as 575 species, although in many cases we have personal (unpublished) knowledge regarding habitats in which many species occur.

The taxonomy of Polyplacophora (59 species) has been intensively reviewed recently (see Kaas and van Belle, 1980, 1985a, 1985b, 1987, 1990, 1994). As a group, they probably represent the taxonomically best known molluscs worldwide. The 59 species known from the Gulf of California belong to six families, Ischnochitonidae being the most diverse with 32 species. Thirteen species belong to the Acanthochitonidae, and the rest are more or less evenly distributed among the remaining four families (Table 3). Most chitons live on rocky shores. Thirty-nine species are recorded for rocky substrate; nine have been reported among pebbles. Surprisingly, there is only one record for coral habi- 
TABLE 2. - Number of species of Gastropoda known from the Gulf of California. Data presented by family.

\begin{tabular}{|c|c|c|c|c|c|}
\hline Family & No. species & Family & No. species & Family & No. species \\
\hline Acteonidae & 5 & Embletoniidae & 1 & Pyropeltidae & 1 \\
\hline Addisoniidae & 1 & Epitoniidae & 48 & Ranellidae & 10 \\
\hline Aeolidiidae & 4 & Eubranchidae & 2 & Rastodentidae & 1 \\
\hline Aglajidae & 3 & Eulimidae & 32 & Retusidae & 4 \\
\hline Aldisidae & 1 & Facelinidae & 4 & Rissoellidae & 1 \\
\hline Amathinidae & 3 & Ficidae & 1 & Rissoidae & 24 \\
\hline Anabathridae & 1 & Finellidae & 4 & Rostangidae & 1 \\
\hline Aplysiidae & 8 & Fissurellidae & 25 & Scissurellidae & 2 \\
\hline Architectonicidae & 8 & Flabellinidae & 7 & Scyllaeidae & 1 \\
\hline Arminidae & 2 & Glaucidae & 1 & Seguenziidae & 1 \\
\hline Assimineidae & 1 & Goniodorididae & 2 & Siphonariidae & 5 \\
\hline Asteronotidae & 1 & Gymnodorididae & 3 & Skeneidae & 6 \\
\hline Babakinidae & 1 & Haminoeidae & 7 & Spurillidae & 2 \\
\hline Barleeidae & 14 & Harpidae & 2 & Stiligeridae & 4 \\
\hline Batillariidae & 1 & Hipponicidae & 4 & Strombidae & 4 \\
\hline Bornellidae & 1 & Janthinidae & 3 & Terebridae & 36 \\
\hline Buccinidae & 79 & Juliidae & 2 & Tergipedidae & 1 \\
\hline Bullidae & 2 & Lamellariidae & 4 & Tethyidae & 1 \\
\hline Bursidae & 3 & Lepetidae & 1 & Titiscaniidae & 1 \\
\hline Caecidae & 28 & Lepetodrilidae & 1 & Tonnidae & 1 \\
\hline Caliphyllidae & 1 & Litiopidae & 3 & Tornidae & 2 \\
\hline Calyptraeidae & 28 & Littorinidae & 8 & Triforidae & 2 \\
\hline Cancellariidae & 28 & Lottiidae & 16 & Trimusculidae & 2 \\
\hline Capulidae & 1 & Marginellidae & 9 & Triophiidae & 2 \\
\hline Cassidae & 4 & Melampidae & 7 & Triphoridae & 21 \\
\hline Cavoliniidae & 3 & Mitridae & 17 & Tritoniidae & 2 \\
\hline Cerithiidae & 15 & Modulidae & 3 & Triviidae & 13 \\
\hline Cerithiopsidae & 20 & Muricidae & 83 & Trochidae & 26 \\
\hline Columbellidae & 93 & Naticidae & 24 & Truncatellidae & 1 \\
\hline Conidae & 30 & Neritidae & 3 & Turbinidae & 24 \\
\hline Conualeviidae & 3 & Notodorididae & 1 & Turridae & 184 \\
\hline Coralliophilidae & 9 & Olivellidae & 16 & Turritellidae & 16 \\
\hline Costellaridae & 2 & Olividae & 21 & Tylodinidae & 1 \\
\hline Cylichnidae & 9 & Onchidiidae & 3 & Umbraculidae & 1 \\
\hline Cylindrobullidae & 1 & Onchidorididae & 2 & Vanikoridae & 1 \\
\hline Cypraeidae & 7 & Ovulidae & 6 & Vasidae & 1 \\
\hline Chromodorididae & 16 & Oxynoidae & 2 & Vermetidae & 12 \\
\hline Dendrodorididae & 5 & Patellidae & 2 & Vitrinellidae & 87 \\
\hline Dendronotidae & 1 & Personidae & 4 & Volutidae & 2 \\
\hline Diaphanidae & 1 & Phenacolepadidae & 2 & Xenophoridae & 1 \\
\hline Diastomatidae & 1 & Planaxidae & 7 & Zephyrinidae & 1 \\
\hline Dironidae & 1 & Pleurobranchidae & 5 & & \\
\hline Discodorididae & 5 & Polyceratidae & 3 & & \\
\hline Dorididae & 1 & Potamididae & 4 & Total species & 1530 \\
\hline Dotidae & 2 & Provannidae & 3 & Total families & 135 \\
\hline Elachisinidae & 2 & Pterotracheidae & 2 & & \\
\hline Elysiidae & 3 & Pyramidellidae & 152 & & \\
\hline
\end{tabular}

TABLE 3. - Number of species of Cephalopoda, Polyplacophora and Scaphopoda known from the Gulf of California. Data presented by family.

\begin{tabular}{|c|c|c|c|c|c|}
\hline \multicolumn{2}{|c|}{ Cephalopoda } & \multicolumn{2}{|c|}{ Polyplacophora } & \multicolumn{2}{|c|}{ Scaphopoda } \\
\hline Family & No. species & Family & No. species & Family & No. species \\
\hline Argonautidae & 3 & Acanthochitonidae & 13 & Dentaliidae & 12 \\
\hline Loliginidae & 4 & Chitonidae & 4 & Laevidentallidae & 1 \\
\hline Octopodidae & 9 & Ischnochitonidae & 31 & Siphonodentaliidae & 1 \\
\hline Ommastrephidae & 2 & Lepidochitonidae & 2 & Gadilidae & 4 \\
\hline Onychoteuthidae & 1 & Lepidopleuridae & 5 & Pulsellidae & 2 \\
\hline Thysanoteuthidae & 1 & Mopaliidae & 3 & & \\
\hline Total species & 20 & Total species & 58 & Total species & 20 \\
\hline Total families & 6 & Total families & 6 & Total families & 5 \\
\hline
\end{tabular}

tat, but it is likely that several species associated with low intertidal rocky areas are also found on coral reefs, especially if present in the same area
(Table 4). It should be remembered, however, that true coral reef habitat is rare in the Gulf of California. Sand and mud records for some species 
TABLE 4. - Major habitats occupied by species of molluscs (Pelecypoda, Gastropoda, Scaphopoda, Cephalopoda, Polyplacophora and Monoplacophora). Numbers indicate numbers of species reported for a substrate category. Totals are greater than species number due to presence of some species in several habitats.

\begin{tabular}{lccccccccc}
\hline Grupo & Rock & Sand & Pebbles & Mud & Coral & Mangrove & Marine vegetation & Water column & No data \\
\hline Gastropoda & 537 & 303 & 224 & 235 & 22 & 17 & 31 & 5 & 561 \\
Pelecypoda & 141 & 329 & 44 & 243 & 23 & 73 & 137 & 0 & 107 \\
Scaphopoda & 2 & 14 & 1 & 5 & 0 & 0 & 0 & 7 & 7 \\
Cephalopoda & 3 & 3 & 0 & 2 & 0 & 0 & 0 & 0 & 13 \\
Polyplacophora & 39 & 5 & 9 & 5 & 1 & 0 & 0 & 0 & 1 \\
Monoplacophora & 0 & 0 & 0 & 0 & 0 & 0 & 0 & & 0 \\
\hline
\end{tabular}

are most certainly related to species collected on loose rock at the edge of rocky areas, where sand/mud might co-occur with rocks. No polyplacophorans have been reported from mangrove habitats, nor have any been positively associated with marine vegetation.

Only 20 species of Cephalopoda have been reported from the Gulf of California (Table 3). Although they are an important economic resource, literature on this group in the Tropical Eastern Pacific is scant. Coastal squids (Loliginidae) and octopuses (Octopodidae) number 13 species, whereas the other four families together contain seven species. Some species prefer rocky shores (Octopodidae) or sandy-muddy substrates (Table 4), but because most species are highly mobile they are captured from a relatively wide variety of substrates.

The Gulf is inhabited by 21 species of Scaphopoda (tusk shells) belonging to five families (Table 3). The majority of the species belong to the Dentaliidae (13 species), and the rest are distributed among four families (Table 3). Dentaliidae and other Scaphopoda are found buried in sandy and muddysand substrates. Records of "rocky" and "pebble" habitats probably represent unspecific sampling or reporting in areas where different substrates cooccur (Table 4).

Monoplacophora are represented in the tropical eastern Pacific by just three species of the genus Neopilina, one of which occurs at the SW limit of our study area. It is found below $3500 \mathrm{~m}$, on muddy bottom (probably on small rocks).

\section{Biodiversity by depth}

Considering all species of molluscs for which bathymetric distribution could be clearly established (1886 of a total of 2194 species), diversity at different depth strata varies considerably (Table 5, Fig. 3). As expected, the highest diversity is found in the $0-20 \mathrm{~m}$
TABLE 5. - Number of species post-Keen.

\begin{tabular}{lccc}
\hline & $1972-1980$ & $1981-1990$ & $1991-2000$ \\
\hline Gastropoda & 32 & 28 & 11 \\
Pelecypoda & 3 & 7 & 5 \\
Polyplacophora & 3 & 13 & 1 \\
Scaphopoda & 1 & 0 & 0 \\
Cephalopoda & 0 & 1 & 0 \\
\hline
\end{tabular}

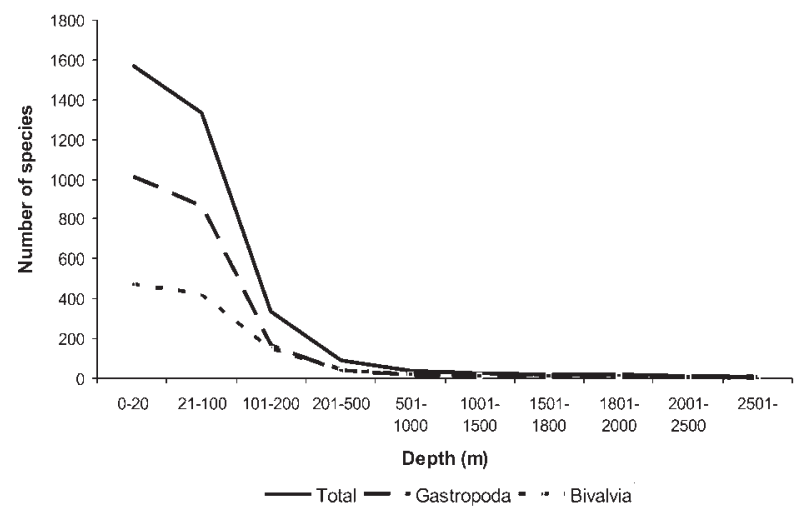

FIG. 3. - Distribution of mollusc biodiversity expressed as number of known species by depth strata (depths intervals not represented at same scale).

depth range (1569 species; $72 \%$ ), and the lowest (nine species) at depths greater than $2500 \mathrm{~m}$. There is a strong reduction in biodiversity from $101 \mathrm{~m}$ to greater depths for all groups. Obviously, a significant number of species occur in more than one defined depth stratum. Molluscan diversity tends to stabilize below 500 $\mathrm{m}$ and relatively similar numbers of species are found in the 500-1000 m strata and the 1500-2000 m strata. When considered separately, a similar trend is observed for the two major groups of molluscs: Bivalvia and Gastropoda (Fig. 3).

Analysis of depth distribution of Bivalvia indicates that 474 species $(84 \%)$ are found in the $0-20 \mathrm{~m}$ coastal fringe and a similar number (423 species; $75 \%$ ) between 21 and $100 \mathrm{~m}$. Gastropoda are better represented in shallow waters: 1011 species $(66 \%)$ 
and 861 species $(56 \%$ ) in the $0-20 \mathrm{~m}$ and $20-100 \mathrm{~m}$ depth strata, respectively. It should be emphasised, however, that depth data are unknown for $19 \%$ of the Gulf gastropods, whereas fewer than $2 \%$ of pelecypod species lack these data (Table 5).

No cephalopod species occurring in the Gulf have been reported from depths below $1001 \mathrm{~m}$. Onychoteuthis banksi (Leach, 1817) and Stenoteuthis oualaniensis (Lesson, 1830) occur at depths of 800 and $1000 \mathrm{~m}$, respectively. Polyplacophora are mostly shallow to intermediatedepths species. Lepidopleuros scrippsianus Ferreira, 1980, has been described from specimens collected from 2507 to $2891 \mathrm{~m}$, while Placiphorella atlantica Verrill and Smith, 1882 is reported from depths between 155 and $2000 \mathrm{~m}$. Scaphopoda are represented below $1001 \mathrm{~m}$ by a significant number of species (Table 5).

\section{Biodiversity in the northern, central and southern Gulf}

In the Gulf of California, invertebrate diversity generally tends to decrease from south to north. A reduction of species number along a south-to-north latitudinal gradient has been shown separately for stomatopods (Hendrickx and Salgado-Barragan, 1991), decapod crustaceans (Hendrickx, 1992), and the Peracarida (Hendrickx et al., 2002). An analysis of species occurrence in the Gulf of California's three main regions (northern, central and southern Gulf; as defined by Findley and Brusca, 2005, and Brusca et al., 2005) shows a somewhat distinct pattern. All species included, molluscs of the upper Gulf number 990 species, while those of the central Gulf number 1479 species (Fig. 4). Surprisingly, those of the southern Gulf number only 1376

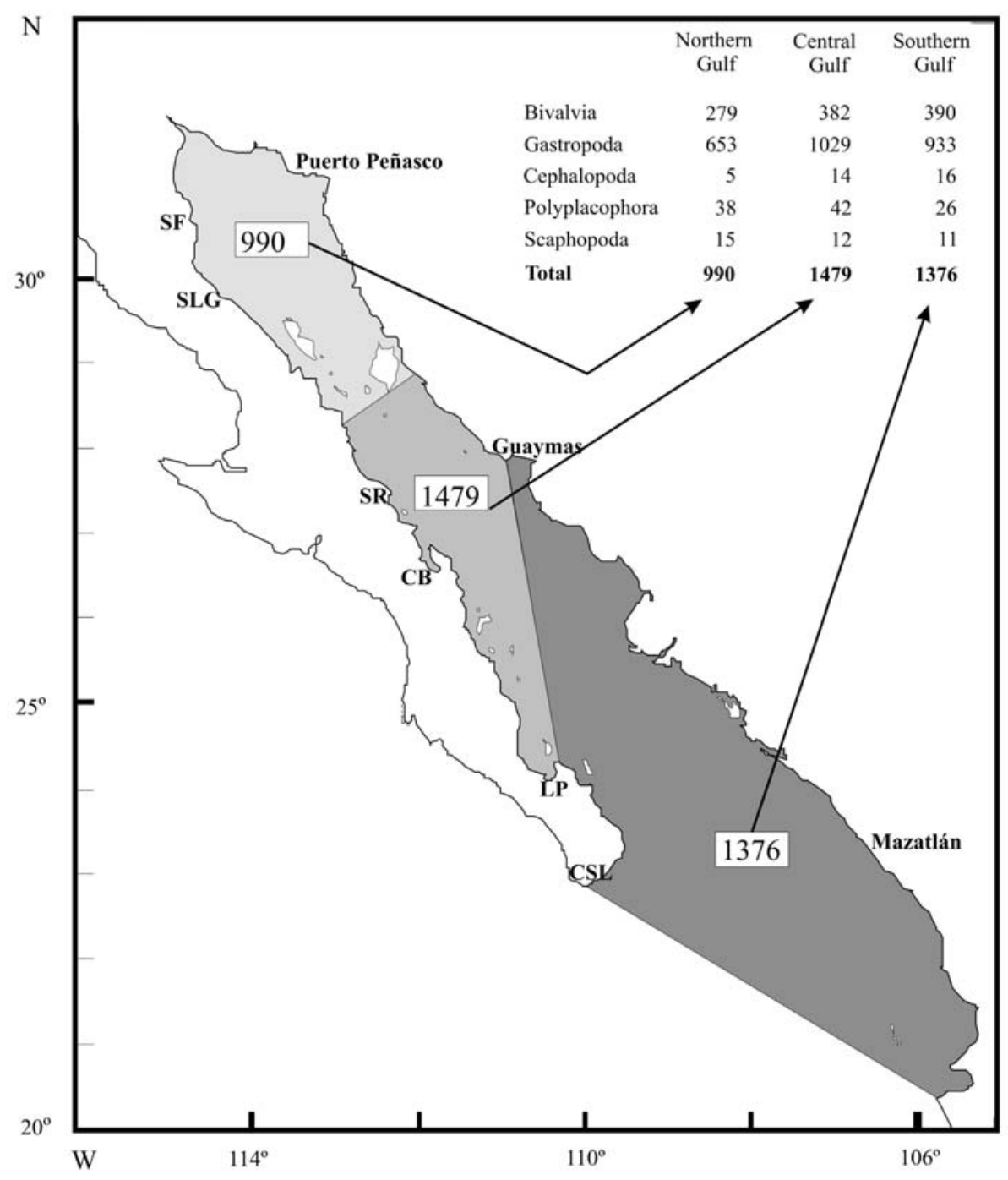

FIG. 4. - Distribution of molluscs in the northern, central and southern Gulf of California. 

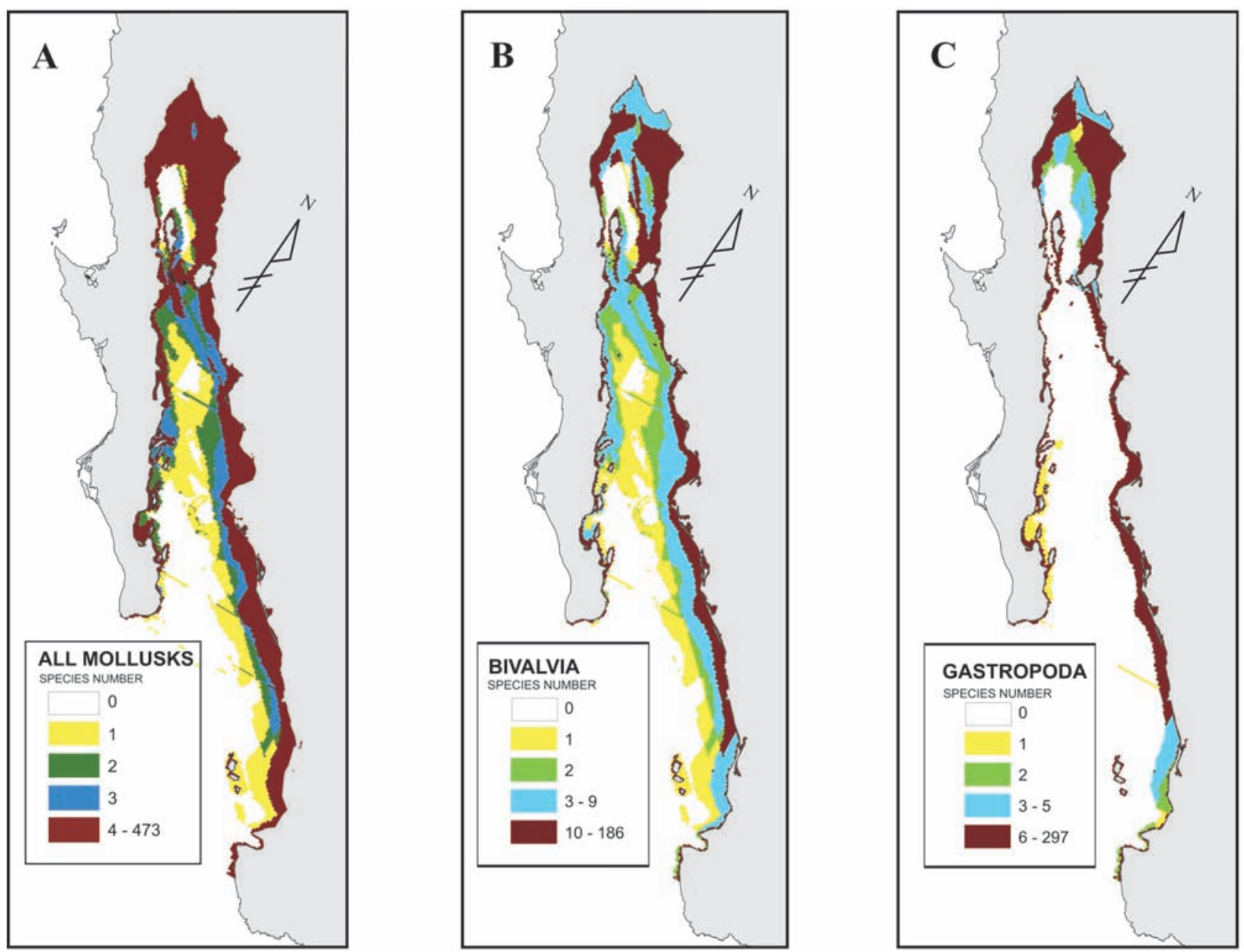

FIG. 5. - All molluscs. Number of species in different areas based on the $2 \times 2 \mathrm{~nm}$ squares.

species, $7 \%$ fewer than in the central Gulf. This is due mostly to a higher biodiversity of Gastropoda in the central Gulf than in the southern Gulf (1029 vs. 933 species), and to a lesser extent a similar situation for the other molluscan groups.

\section{Georeferenced biodiversity model}

For all molluscs, and for the classes Bivalvia and Gastropoda, the BIODIX-1 program generated a colour-coded map representing biodiversity distribution patterns (Fig. 5A-C). The $20 \%$ accumulative classes used in the analysis defined five biodiversity clusters-areas where no species are reported to occur; areas with one species; areas with two species; areas with 3-15 species; and areas with 16 to 473 species. The 473 species value obviously corresponds to the highest molluscan diversity expected in any given $2 \times 2 \mathrm{~nm}$ square within the Gulf. It represents $31 \%$ (473 out of 1528 species) of all presently known Gulf species. As expected, the higher biodiversity values are associated with the coastal fringe and surrounding islands where shallow waters are found. The lowest biodiversity ( 0 or 1 species recorded) is associated with deep waters in the Gulf, particularly in the basin areas (e.g., the Guaymas, Carmen, Farallon and Pescadero Basins) and at the Gulf's entrance, which can be clearly located on the biodiversity map by blanks areas (Fig. 5A). The deeper central section of the northern Gulf $(>200 \mathrm{~m}$ depth) is also clearly indicated by a blank area surrounding Angel de la Guarda Island, which is somewhat surprising and reflects an obvious lack of consistent sampling in the area. The higher biodiversity values (3-15 and 16-473 species ranges) obtained through the BIODIX-1 analysis closely follow the continental platform's outermost margin, wide along the continental and northern Gulf shores and narrow along the Baja California peninsula shore, south of San Luis Gonzaga Bay (ca. 2950’N). 
Analysis of Bivalvia and Gastropoda, by far the two most diverse groups of molluscs in the Gulf (and worldwide), reveals roughly the same results so far as distribution of biodiversity is concernedhigh values in coastal systems and on the shelf, including the areas surrounding the islands. Gastropoda are much more species rich in shelf and upper slope areas, with fewer deep-water representatives than Bivalvia (Figs. 5B, C).

\section{DISCUSSION}

With a total of 2194 reported species of marine molluscs, the Gulf of California is probably the most biodiverse body of water that extends into warm temperate latitudes (i.e., the northernmost region of the Gulf). However, because the northern Gulf is isolated from the tropical Pacific by warm waters in the southernmost Gulf and Cape Region, few temperate species occur in the Gulf, and little genetic exchange takes place between the northern Gulf and open Pacific regions (see Brusca, 1980; Hendrickx, 1992).

In her monumental monograph "Sea Shells of the Tropical West America", Keen (1971) included 800 species of Bivalvia, 2428 species of Gastropoda, 56 of Polyplacophora, 25 of Scaphopoda and 13 of Cephalopoda. Skoglund's review of the Bivalvia (1991) and Gastropoda (1992) of the tropical eastern Pacific revealed an additional 118 species of bivalves and 360 species of snails and slugs that have been added to the tropical eastern Pacific fauna since Keen's 1971 monograph. This represents an increase of roughly $15 \%$ to the tropical eastern Pacific Bivalvia and Gastropoda fauna in 30 years (few new species of less diverse classes have been added). Comparatively, The Macrofauna Golfo Database indicates 104 additional species (mostly bivalves and gastropods) described from the Gulf since Keen's (1971) monograph, most having been described in the 1970s and 1980s (see Table 5). This represents ca. $5 \%$ of the total number of species included in our database, $1 / 3$ of the species described for the entire tropical region in a shorter period (1971-1991). This is a clear indication that sampling efforts have significantly increased the number of western Mexico-northern Peru species, as has also occurred with other groups of invertebrates in the last two decades.

Although a reduction in macrofaunal diversity in deeper waters is a general trend, figures for the Gulf are most probably underestimated-as in others areas of the world-due to lack of adequate sampling, particularly below $60 \mathrm{~m}$ depth, and in shallow water along the Baja California peninsula, which is still difficult to access except for some areas where good roads reach the coast (e.g., La Paz Bay, Santa Rosalia, Concepción Bay and San Felipe).

The BIODIX-1 program used during this analysis is versatile. It allows any changes in the original BIOTAX and ENVIRONM databases for a given species or for any kind of environmental data in such a way that input of new data and data corrections are allowed at any time. In addition to this, the analysis can be performed for the entire ecosystem (e.g., the Gulf of California) or restricted to a portion of the region Furthermore, the definition of "biodiversity" categories (i.e., how many species are to be considered in low, medium or high biodiversity ranges) can be selected at will. Selection of "ranges" will result in different distribution patterns of low, medium and high biodiversity that are presented on colour-coded maps. It also allows one to estimate or predict biodiversity for selected geographic areas (see Hendrickx et al., 2002, for Crustacea of the State of Sinaloa) or bathymetric range. As a tool, it provides a quick glance at distribution patterns that can suggest areas where management or conservation measures are needed (e.g., biodiversity "hot spots") or areas where biodiversity is low, suggesting that increased sampling might be needed.

\section{ACKNOWLEDGEMENTS}

The authors wish to thank Lloyd T. Findley, coordinator of the original Macrofauna Golfo project, and J.C. Barrera, M. A. Carvajal and A. Robles who promoted the project since its beginning in 1994. We thank the institutions that provided financial support (CIDESON-Mexico; Conservation International, Mexico; CONABIO-Mexico) and infrastructure support (Unidad Académica Mazatlán, UNAM, Mexico; College of Charleston, South Carolina; Arizona-Sonora Desert Museum, Tucson) during the course of this project. Numerous people assisted with data compilation and the literature review, including Y. Delgado, J.A. Esparza Haro, M. Ruíz, S. Trautwein, and R. Wetzer. We also thank our colleagues who provided data, reprints, and hard-to-find literature, and those who reviewed 
sections of the original database - in particular we wish to thank F. Fiers, P. Willenz, and C. Debroyer, IRSNB, Belgium. We also thank David Serrano who provided the estimation of coastal length for the Gulf of California.

\section{REFERENCES}

Brusca, R.C. - 1980. Common Intertidal Invertebrates of the Gulf of California. 2nd. Ed. University of Arizona Press, Tucson, Arizona.

Brusca, R.C. and B.R. Wallerstein. - 1979. Zoogeographic patterns of idoteid isopods in the northeast Pacific, with a review of shallow-water zoogeography for the region. Bull. Biol. Soc. Wash., 3: 67-105.

Brusca, R.C., E. Kimrey and W. Moore.-2004. A seashore guide to the northern Gulf of California. Arizona-Sonora Desert Museum. Tucson, Arizona.

Brusca, R.C., L.T. Findley, P.A. Hastings, M.E. Hendrickx, J. Torre Cosio and A.M. van der Heiden. - 2005. Macrofaunal Biodiversity in the Gulf of California. In: J.-L. E. Cartron, G. Ceballos, and R. Felger (eds.), Biodiversity, Ecosystems, and Conservation in Northern Mexico, pp. 179-203. Oxford University Press, NY.

Findley, L.T. and R.C. Brusca. - 2005. Presentation of the Data [Presentación de Datos]. In: M. E. Hendrickx, R. C. Brusca and L. T. Findley (eds), A Distributional Checklist of the Macrofauna of the Gulf of California, Mexico. Part I. Invertebrates [Listado y Distribución de la Macrofauna del Golfo de California, México, Parte I. Invertebrados], pp. 2540. Arizona-Sonora Desert Museum and Conservation International. Tucson, Arizona, USA.

Hatcher, B.G., R.E. Johannes and A.I. Robertson. - 1989. Review of research relevant to the conservation of shallow tropical marine ecosystems. Oceanogr. Mar. Biol., Annu. Rev., 27: 337-414

Hendrickx, M.E. - 1992. Distribution and zoogeographic affinities of decapod crustaceans of the Gulf of California, Mexico. Proc. San Diego Soc. Nat. Hist., 20: 1-12.

Hendrickx, M.E. and J. Salgado-Barragán. - 1991. Los estomatópodos (Crustacea: Hoplocarida) del Pacífico mexicano. Publ. Esp. Inst. Cienc. Mar y Limnol. UNAM., 10: 1-200.

Hendrickx, M.E., R.C. Brusca and G. Ramírez Reséndiz. - 2002. Biodiversity of macrocrustaceans in the Gulf of California, Mexico. In: M.E. Hendrickx (ed.). Contributions to the Study of East Pacific Crustaceans 1 [Contribuciones al Estudio de los Crustáceos del Pacífico Este 1], pp. 349-368. Instituto de Ciencias del Mar y Limnología, UNAM. México.

Hendrickx, M.E., R.C. Brusca and L.T. Findley (eds.). - 2005. A Distributional Checklist of the Macrofauna of the Gulf of California, Mexico. Part I. Invertebrates [Listado y Distribución de la Macrofauna del Golfo de California, México, Parte I. Invertebrados]. Arizona-Sonora Desert Museum. 429 pp.
Ibarra Obando, S.E. - 1998. Cambio global y zona costera: Una oportunidad para México. Ciencia, 49: 5-14.

Kaas, P. and R.A. Van Belle. - 1980. Catalogue of living chitons (Mollusca: Polyplacophora). W. Backhuys Pub. Rotterdam.

Kaas, P. and R.A. Van Belle. - 1985a. Monograph of Living Chitons (Mollusca: Polyplacophora). Vol. 1 Order Neoloricata: Lepidopleurina. E.J. Brill \& W. Backhuys, Leiden.

Kaas, P. and R.A. Van Belle. - 1985b. Monograph of Living Chitons (Mollusca: Polyplacophora). Vol. 2. Suborder Ischnochitonina. Ischnochitonidae: Schizoplacinae, Callochitoninae and Lepidochitoninae. E.J. Brill \& W. Backhuys, Leiden.

Kaas, P. and R.A. Van Belle. - 1987. Monograph of Living Chitons (Mollusca: Polyplacophora). Vol. 3. Suborder Ischnochitonina. Ischnochitonidae: Chaetopleurinae and Ischnochitoninae (pars). Additions to vols. 1 \& 2. E.J. Brill \& W. Backhuys, Leiden.

Kaas, P. and R.A. Van Belle. - 1990. Monograph of Living Chitons (Mollusca: Polyplacophora). Vol. 4. Suborder Ischnochitonina: ischnochitonidae: Ischnochitoninae (continued). Additions to Vols. 1, 2 \& 3. E. J. Brill, Leiden.

Kaas, P. and R.A. Van Belle. - 1994. Monograph of Living Chitons (Mollusca: Polyplacophora). Vol. 5. Suborder Ischnochitonina: Ischnochitonidae: Ischnochitoninae (concluded). Callistoplacinae; Mopaliidae. Additions to Vols. 1-4. E.J. Brill, Leiden.

Keen, A.M. - 1971. Sea Shells of Tropical West America. Marine Mollusks from Baja California to Peru. 2nd ed. Stanford Univ. Press, Stanford, Calif.

May, R.M. - 1992. How many species inhabit the earth? Sci. Am., 267: 18-24.

McNeely, J.A., K.R. Miller, W.V. Reid, R.A. Mittermeier and T.B. Werner. - 1990. The information required to conserve biological diversity. In: Conserving the world's biological diversity, pp. 7181. Chapter VIUCN, WRI, CI, WWF-US, The World Bank.

Parker, R.H. - 1964. Zoogeography and ecology of some macroinvertebrates particularly mollusks, in the Gulf of California and the Continental slope off Mexico. Vidensk. Medd. Dan. Naturhist. Foren., 126: 1-178.

Poore, G.C.B. and G.D.F. Wilson. - 1993. Marine species richness. Nature, 361: 597-598.

Skoglund, C. - 1991. Additions to the Panamic Province bivalve (Mollusca) literature 1971 to 1990 . The Festivus, 22 (2): 1-63.

Skoglund, C. - 1992. Additions to the Panamic Province Gastropod (Mollusca) literature 1971 to 1992. The Festivus, 24, (Supl. 2): 1-169.

Solow, A.R. - 1995. Estimating biodiversity. Calculating unseen richness. Oceanus, 9-10.

Thorpe, J.E., G.A.E. Gall, J.E. Lannan and C.E. Nash. 1995. Conservation of fish and shellfish resources: Managing diversity. Academic Press.

van der Heiden, A.M. and M.E. Hendrickx. 1982. Inventario de la fauna marina y costera del sur de Sinaloa, México. Univ. Nac. Autón. México, Inst. Cienc. del Mar Limnol., Mazatlán. México.

Scient. ed.: P. Sánchez.

Received February 6, 2007. Accepted June 27, 2007

Published online October 3, 2007. 